\title{
THE APPLICABILITY OF DISINTEGRATION TESTS FOR COHESIVE ORGANIC SOILS
}

\author{
Anne-Katrin GROßE ${ }^{\mathrm{a}, \mathrm{b}}$, Stefan CANTRÉ ${ }^{\mathrm{b}}$, Fokke SAATHOFF ${ }^{\mathrm{b}}$ \\ ${ }^{a}$ Department of Maritime Systems, Faculty of Interdisciplinary Research, Universität Rostock, \\ Justus-von Liebig Weg 6, 18059 Rostock, Germany \\ ${ }^{b}$ Chair of Geotechnics and Coastal Engineering, Universität Rostock, Justus-von-Liebig Weg 6, \\ 18059 Rostock, Germany
}

Submitted 12 Nov. 2013; accepted 28 Apr. 2014

\begin{abstract}
The use of ripened fine-grained organic dredged materials as construction materials, e.g. as top soil on slopes such as landfills or dikes, is an important contribution to environmental engineering science. The materials are legally considered a waste and need to be beneficially re-used. Therefore, not only standard geotechnical parameters have to be determined but also their erosion resistance which is a particularly critical environmental parameter. There is a variety of different tests to determine the flow dependent erosion resistance of soils, such as the erosion function apparatus (Briaud et al. 2001). In this study, however, the focus lays on the aggregate stability as an indicator for the erosion resistance under static loading, which can be determined using wet sieving and disintegration tests. The disintegration tests after Weißmann (2003) and Endell (RPW 2006) have a similar setup; however, the specific boundary conditions for the tests as well as the evaluation procedures are different. Weißmann proposed his test to determine the erosion stability of dike cover materials while the Endell test should be used for mineral sealing liners in navigation channels. In this study both tests have been used to evaluate the aggregate stability of fine-grained organic dredged materials that have been installed in large-scale research dike facilities and in the recultivation layers of different landfills. The materials showed good visual performance with respect to rainfall induced erosion so far; however, problems in determining erosion and aggregate stability indices limit the value of the studies: both disintegration tests investigated have major limitations with respect to the organic soils tested. Particularly the evaluation methods are not suitable for the soils but also some boundary conditions are critical and are discussed in this paper. The gained knowledge is a valuable basis for the development of standard characterisation methods for dredged materials in environmental and geotechnical applications.
\end{abstract}

Keywords: soil erosion, disintegration tests, aggregate stability, waste management technologies, cohesive organic soils, dredged material, marsh clay, marl, environmental sustainability.

\section{Introduction}

Soil erosion plays an important role both in agricultural and geotechnical environments. In agriculture the workability and long-term availability of arable soils are very important issues while the erosion stability of slopes, (e.g. at dams and dikes) is of great interest in the geotechnical context. Most importantly, international soil protection legislation states that the top soil should always be protected against relocation by erosion. Coastal dikes are often constructed in environmentally sensitive areas and in spite of their flood protection function and the associated maintenance as a coastal protection structure dikes are large environmental earth constructions that characterise the coastal landscape. They are usually made of a sand core, a cohesive top layer with high erosion resistance, and a grass cover. At the German Baltic Sea coast the cohesive layer is usually made of marl while at the North Sea coast it is mostly made of marsh clay which sometimes has considerable organic contents. During the last few years also dried fine-grained organic dredged materials have been investigated to be used in dike and landfill construction as protective and/or recultivation layers. These materials can be characterised as young cohesive organic soils, which is the focus of this paper.

Dredging means the removal of sediments from water bodies by excavators or hydraulic dredgers. It is a

Corresponding author: Anne-Katrin Große

E-mail: anne-katrin.grosse@uni-rostock.de 
necessary operation in waterway and harbour maintenance but also in hydraulic construction works and ecological revitalisation projects. The major amount of the removed sediments is usually relocated within the water body which means the sediments are transported to another location and dumped to underwater reservoirs. However, due to environmental sustainability the relocation of contaminated and cohesive organic sediments is restricted in most areas of the world. In the Baltic Sea there is, for example, a general understanding under the HELCOM convention only to relocate clean sands (regarding precaution values usually provided by national law of the Baltic Sea bordering states).

Cohesive organic dredged sediments are usually taken ashore to be deposited on special land-fills (mainly if contaminated) or to be re-used beneficially according to the respective environmental regulations, e.g. the soil protection law, ground water protection law, and other soilwater related regulations (in Germany: BBodSchG 1998; BBodSchV 1999; WHG 2009). The re-use of fine-grained organic dredged materials in agriculture and landscaping has become an acknowledged method (Sigua et al. 2004; Canet et al. 2003). Usually the materials are processed before re-use. In most cases the materials are therefore pumped into containment areas where they are dewatered. After some time, the mud is taken out of the dredging polders and put on heaps on adjacent drying fields where the ripening process starts. The so ripened soil-like material is usually an in-homogenous mix of mineral and organic soil particles, depending on the dredging project. However, sometimes the dredged materials are also separated in so-called classification polders where the coarse and medium coarse sandy material settles around the inlet pipes, followed by different mixed soils with decreasing sand and increasing silt, clay and organic fractions down to the polder outlet where the very fine-grained organic sludge is deposited. Then particular batches can be classified and separately processed to receive better qualities for the re-use of the materials. The Hanseatic City of Rostock successfully runs two such containment areas as waste management technology with classification polders to process defined ripened soils for re-use. The mixed soils and finegrained organic materials have been used in landscaping, agriculture and recultivation layers on landfills so far.

The project DredgDikes deals with the application of ripened dredged material in dike construction. Within the project three different cohesive organic dredged sediments have been installed in a full scale research dike facility (Cantré, Saathoff 2013). All materials are generally cohesive soils with an organic content of five to ten per cent. Visually, they seem to have considerable erosion resistance when installed and compacted with caterpillars. In contrast, laboratory flume tests showed rather low erosion resistance with respect to overflowing. Particularly for coastal and river dikes the time dependent stability of the erosion protection layer with respect to a static water loading is of great interest because the soil aggregates may decompose due to aggregate explosion and swelling phenomena which may lead to dike failure. Therefore, two different disintegration tests have been investigated to study the aggregate stability of the materials as an index for the erosion resistance under static conditions. However, some important limitations regarding both the test setups and the evaluation methods disparage their conclusiveness which will be discussed in this paper. The results will be used to develop a set of characterisation tools for dredged materials in environmental and geotechnical engineering applications.

\section{Basics}

\subsection{Aggregate and erosion stability}

Erosion stability is defined as the stability against "the replacement and the transport of soil particles along the surface" (Blume et al. 2010) and can be characterized as a combination of the stability of the overall soil texture and the stability of the aggregates within the texture, which are agglomerations of fines of different mineral grains mixed with organic carbon, lime and other soil components (Le Bissonnais 1996).

Surface erosion can be triggered from water, wind, snow melting or gravitation and is influenced by different processes like rainfall or surface run-off. Here, only water induced erosion is investigated. The main processes of soil erosion by water are soil displacement, soil transport and soil deposition (Blume et al. 2010). The soil displacement is the release of erodible material and includes subprocesses like the destruction of soil aggregates and the siltation of bounded particles. The soil structure consists of single grains or aggregates which are characterized by their external shape and size or their internal structure (Blume et al. 2010). The stability of soil aggregates differs with respect to water and pressure which influence the mechanical capacity, the siltation and the erosion risk. An aggregate can be described as stable if the particle position does not change by voltage variation. Also, high organic contents improve the stability of aggregates against water immersion due to inter-particle cohesion with organic carbon (Chenu et al. 2000; Cantón et al. 2009; Dal Ferro et al. 2012).

The definition of aggregate stability and soil structure stability is not standardised and both definitions are often used synonymously (Ametzketa 1999). The German DIN standard 19683-16 (2009) defines aggregate stability as an important parameter for the siltation of soils and provides a comparison of the stability of different agricultural farmlands. Here, aggregate stability is defined as the resistance of soil particles to their structure (Blume et al. 2010). Hartge and Horn (2009) describe aggregate stability as the 
resistance of aggregates against destructive triggers which can be expressed by a shear parameter. The determination of the aggregate stability against water is not trivial because it depends on the surface binding energy of the soil particle, the water cohesion and the adhesion forces. Adhesion is caused by suspended solids that may deposit at the contact points of the soil particles and thus glue the particles together. Both the building and reversibility of aggregates depend on the degree of drying and the type of rehydration and thus on the aggregate size, aggregate density and the pathways through intra aggregate pores are important parameters (Hartge, Horn 2009). Le Bissonnais (1996) also describes a high dependence of water infiltration and soil erosion by aggregate stability. In his opinion the erosion rates are the results of the aggregate disintegration divided into disintegration of macrostructure and dispersion. The aggregate disintegration through water can be the result of a variety of mechanisms, four of which are particularly important (Le Bissonnais 1996):

I. Slaking occurs with overpressure through enclosed air during moisture infiltration and appears when dry aggregates are put fast into water. The disintegration decreases with increasing clay content.

II. Swelling and slaking during wetting and dehydration lead to aggregate blasting. The disintegration increases with increasing clay content.

III. Soil fragments are dissolved by the splash effect if the kinetic energy of rain drops is high enough to cause disintegration. This phenomenon occurs most often with wet soils because the aggregates are weaker and can be dissolved more easily.

IV. Physico-chemical dispersion means the reduction of attraction between single colloid particles during drainage of soils and is facilitated with slaking and swelling. It is one of the most effective processes of aggregate destruction. Auerswald (1993) on the other hand focuses on the influence of the initial soil moisture and the resulting erosion process to explain aggregate stability. Investigations about the shear strength from soils or aggregates show lower strengths with increasing moisture. Investigations with a sudden wetting, however, show a lower aggregate blasting at increasing moisture content. Hereby, the initial moisture seems to have an influence on the mechanisms of temperature weakening, impact hardness, air blasting and swelling pressure with respect to aggregate disintegration (Auerswald 1993):

I. With penetrating water a heat front proceeds into the aggregates due to an energy release that weakens the aggregate bounding substances. This mechanism is called temperature weakening and is important for soils with moistures below $10 \%$ or above $30 \%$ (gravimetric).

II. The soil stiffness exponentially increases with decreasing soil moisture, thus the impulse recurrence from a rain drop to the soil increases.
III. The decrease of soil moisture causes an increase of air filled pores. If water penetrates quickly into an aggregate without air escaping, an overpressure occurs inside the aggregate, leading to air blasting. This phenomenon increases with decreasing moisture content.

IV. Quick and irregular wetting of aggregates causes irregular swelling. The resulting drag stress causes aggregates to break-up.

\subsection{Methods to determine erosion stability}

To determine the soil erosion stability a variety of methods have been proposed (Table 1) which can be divided into tests to determine the erosion resistance of the whole soil texture (e.g. laboratory flumes or erosion function apparatus after Briaud) and tests to determine the aggregate stability (e.g. wet-sieving methods, flow-rate methods, and water-immersion methods). In the following, different tests to determine the aggregate stability will be briefly reviewed.

For the wet-sieving tests air-dried soil aggregates are put into a sieve-diving apparatus with different sieve sizes to be moved vertically through a liquid medium (water or ethanol). Thereby, the instable aggregates are resolved in the liquid and the remaining grains are automatically sieved. The mass left on the sieve is measured and related to the initial mass.

Table 1. Overview of tests to determine aggregate stability

\begin{tabular}{ll}
\hline \multicolumn{1}{c}{ Method } & \multicolumn{1}{c}{ Test } \\
\hline \multirow{3}{*}{ Wet-sieving } & German DIN-standard 19683-16 \\
& $\begin{array}{l}\text { Hartge/Horn } \\
\text { Le Bissonnais }\end{array}$ \\
\hline \multirow{2}{*}{ Flow-tests } & Pinhole test after ASTM D 4647-06 \\
& Modified pinhole test after BAW \\
\hline \multirow{3}{*}{ Dispersion-tests } & Dispersion test after ASTM D 4221-99 \\
& Crumb-test after ASTM D 6572-06 \\
& Disintegration test after Weißmann \\
& Disintegration test after Endell (BAW) \\
\hline
\end{tabular}

The pinhole test after ASTM standard D 4647-06 and the modified pinhole test (RPW 2006) represent direct qualitative measurements of the dispersibility of compacted clay. A defined hole is put into a compacted soil sample and a water flow is realised through the hole. After the test the increase in hole diameter is measured and related to a degree of aggregate stability.

The disintegration of aggregates or compacted samples in water immersion is analysed using dispersion tests. They can be performed using the crumb test after ASTM standard D 6572-06, the modified crumb test after Haghighi et al. (2012), the dispersion test after ASTM 
standard D 4221-99 or different disintegration tests. In this paper the disintegration tests after Endell (enhanced by the Federal Waterways Engineering and Research Institute, BAW) and Weißmann have been studied.

\section{Investigated soil materials}

For the investigations five different soils were used: three different fine-grained, organic dredged material batches from a containment area near Rostock, Germany and two standard dike cover materials (marl and marsh clay). Apart from their composition the dredged materials differ in their ripening time: materials $\mathrm{M} 1$ and $\mathrm{M} 3 \mathrm{had}$ been ripened for 5 years, while material M2 had been ripened for

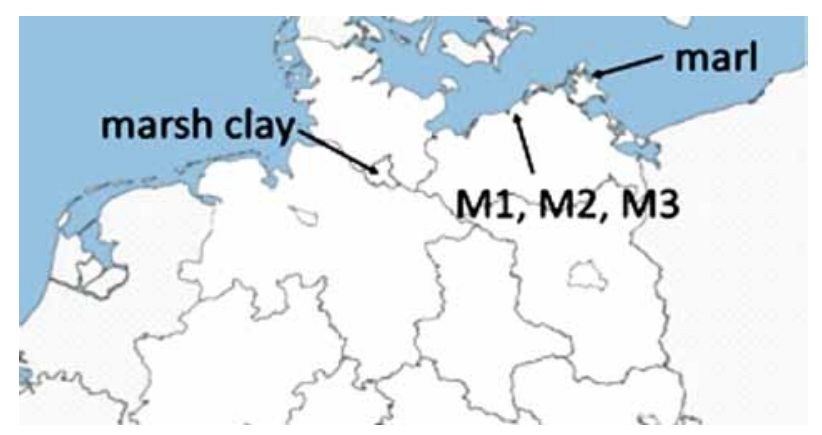

Fig. 1. Locations from where the soil samples were taken

Table 2. Reliable results of geotechnical characterisation

\begin{tabular}{lccccc}
\hline \multicolumn{1}{c}{ Material } & M1 & M2 & M3 & Marl & $\begin{array}{c}\text { Marsh } \\
\text { clay }\end{array}$ \\
\hline Clay [\%] & $25-28$ & $22-25$ & 15 & 5 & 17 \\
Sand [\%] & $29-34$ & $40-47$ & 54 & 89 & 46 \\
W [\%] & $61-68$ & $55-73$ & 46 & 13 & 21 \\
OM [\%] & $10-11$ & $9-10$ & 6 & 0.9 & 1.7 \\
LC [\%] & $9-10$ & 8 & 10 & 12 & 0.9 \\
$c_{u}[\mathrm{kPa}]$ & $53-132$ & $19-34$ & 120 & 24 & 83 \\
$\varphi\left[^{\circ}\right]$ & $28-30$ & $28-31$ & 30 & 42 & 66 \\
$c\left[^{\circ} \%\right]$ & $35-47$ & $13-19$ & 59 & 15 & 3 \\
$k_{f}[\mathrm{~m} / \mathrm{s}]$ & $5 \mathrm{E}-08$ & $8 \mathrm{E}-10$ & $5 \mathrm{E}-09$ & $4 \mathrm{E}-08$ & $4 \mathrm{E}-10$ \\
\hline
\end{tabular}

Table 3. Preliminary results of geotechnical characterisation

\begin{tabular}{lccccc}
\hline \multicolumn{1}{c}{ Material } & M1 & M2 & M3 & Marl & $\begin{array}{c}\text { Marsh } \\
\text { clay }\end{array}$ \\
\hline LL [\%] & $80-98$ & $64-88$ & $52-57$ & 17 & 36 \\
PL [\%] & $75-81$ & $54-67$ & $49-54$ & 13 & 22 \\
SL [\%] & 58 & $42-47$ & 51 & 16 & 22 \\
PI [\%] & $4-22$ & $11-24$ & $3-4$ & 4 & 14 \\
CI [-] & $2-5$ & $0-1$ & $2-4$ & 1 & 1 \\
$w_{\text {opt }}[\%]$ & $40-43$ & $32-35$ & 31 & 9.2 & 14 \\
OD [g/cm $\left.{ }^{3}\right]$ & $1.1-1.2$ & 1.3 & 1.4 & 2.1 & 1.8 \\
\hline
\end{tabular}

two years at the time of the investigation. For materials M1 and M2 three subsamples were taken respectively. The marsh clay batch was sampled from a dismantled dike cover layer in Hamburg Port while the marl was originally extracted from the Baltic Sea off the coast of the Island of Rügen (Fig. 1).

All materials were investigated with respect to their soil mechanical characteristics such as water content, grain-size distribution, compaction parameters, shear strength, water permeability and shear parameters, principally according to the German DIN-standards for soil mechanical analyses (DIN... 1998). Because of the high organic content of the dredged materials the grain-size distribution was determined according to DIN ISO 11277 for fine-grained, organic soils. For the organic content the TOC (Total Organic Carbon) value was determined after DIN ISO 10694 with an elemental analyser at temperatures above $1000{ }^{\circ} \mathrm{C}$, because the marine dredged sediments possess high lime contents which influence the results from a $550{ }^{\circ} \mathrm{C}$ muffle furnace.

The results of the geotechnical characterization are shown in Table 2 and Table 3. Because of different challenges using the standardized DIN characterization for the specific dredged materials the tables are divided into reliable and preliminary results.

\section{Disintegration tests}

For both disintegration tests in this study cylindrical compacted samples with different water contents are put into a wire mesh basket which is connected to an electric scale. The disintegration is measured by recording the weight loss caused by the dropping of aggregates at water immersion. The dropping of aggregates is described as "crumbling" in the following while disintegration describes the status of the overall sample. Both disintegration tests use the weight loss as a function of time for further analysis. The principle of the test procedure is shown in Figure 2. In spite of the similar setup of the disintegration tests and similar processes studied the tests differ in several important issues which will be discussed in the following.

\subsection{Disintegration test after Endell}

The disintegration test after Endell (enhanced by the Federal Waterways Engineering and Research Institute, BAW) is used to estimate the erosion susceptibility of clay to be used in waterways construction. Sealing compounds with higher disintegration are more sensitive to erosion which is especially interesting while installing mineral sealing liners while they are still uncovered (RPW 2006).

For the analysis at least five proctor compacted samples (proctor power of $0.6 \mathrm{MNm} / \mathrm{m}^{3}$ ) with a diameter of $2 \mathrm{~cm}$ and a height of $4 \mathrm{~cm}$ are used. The samples 
are each put into a wire mesh basket which is not specified with respect to its dimensions. It is connected to an electric scale and put into a water basin with distilled water (Fig. 2).

After the RPW (2006) the weight has to be recorded until a constant weight is reached, but not less than 24 hours. The result of this test is the disintegration number $Z(t)$ as a function of time (Eqn (1)):

$$
Z(t)=\frac{A 1-A(t)}{A 1-A 2},
$$

where: $Z(t)$ - disintegration number as function of time; $A 1$ - uplift sample weight including mesh basket weight [g] at the beginning; $A(t)$ - uplift sample weight including mesh basket weight [g] at the time $t$ of the test; $A 2$ - uplift mesh basket weight $[\mathrm{g}]$ without sample.

To compare different samples the disintegration number after 8 hours $Z(8)$ is proposed. Therefore, it must be ensured that all dropped particles drop out of the wire mesh basket; otherwise, the test has to be repeated. According to Endell there is one specific moisture content for every soil at which the most significant disintegration occurs. Therefore, the test has to be carried out with at least five different water contents resulting in different undrained shear strengths (e.g. $c_{u}=10 \ldots 70 \mathrm{kPa}$ ). The lowest disintegration should be expected at a water content near the liquid limit because of a reduced water immersion in saturated samples.

RPW (2006) specifies a limit value for the disintegration number of $Z(8)=0.05$. Above this value the soils are defined as susceptible to erosion while soils with a value $Z(8)<0.05$ are defined as erosion resistant. However, there is no standardised limit value for the disintegration number yet.

\subsection{Disintegration test after Weißmann}

The test equipment of Weißmann's disintegration test was developed independently to that of Endell to determine the erosion resistance of marsh clay embankments on sea dikes. The test facility is similar to that of Endell, except little differences (Fig. 3). The wire mesh basket is defined with meshes of $8 \times 8 \mathrm{~mm}^{2}$ and an overall size of $10 \times 10 \times 12 \mathrm{~cm}^{3}$. The soil samples are bigger than those of the Endell test ( $5 \mathrm{~cm}$ for both diameter and height). The water temperature shall have $20{ }^{\circ} \mathrm{C}$ during the entire test and tap water should be used. Nine cylindrical samples have to be prepared in a Proctor apparatus with optimum water content (standard proctor power of $0.6 \mathrm{MNm} / \mathrm{m}^{3}$ ) to guarantee good compaction.

From the nine samples three test series with different water contents are prepared (three repetitions):

(1) Dry sample - dried at $50{ }^{\circ} \mathrm{C}$ to a constant mass;

(2) Standard sample - optimum water content;
(3) Wet sample - lagged with filter paper and put into a water basin for ten minutes, then kept in a desiccator for 24 hours.

The result of the Weißmann test is the time $t_{30}$ when a sample lost $30 \%$ of its initial weight. The maximum testing time is 24 hours, even if the $30 \%$ weight loss cannot be reached; then the material is classified as erosion resistant. According to Weißmann the disintegration time increases with increasing water content and can be described approximately with an exponential curve, shown in

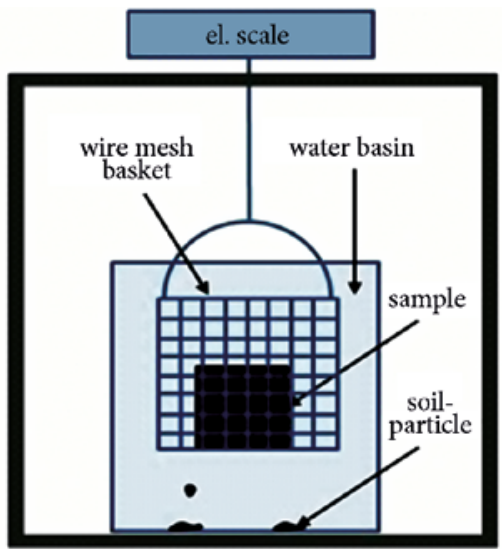

Fig. 2. Schematic of disintegration tests

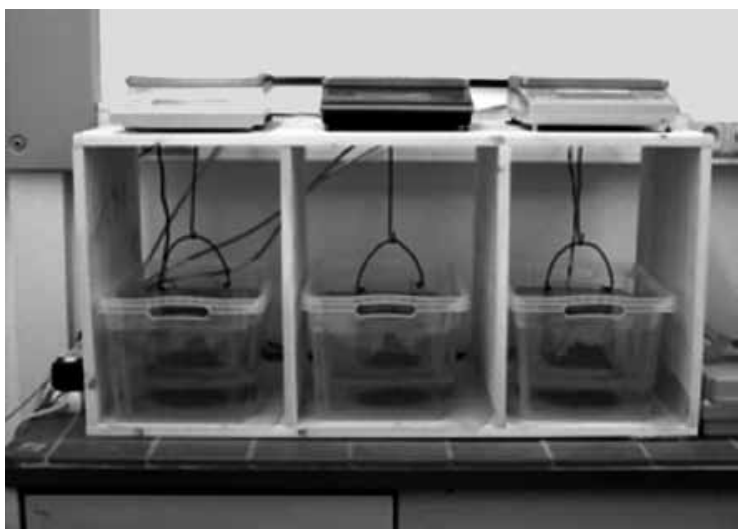

Fig. 3. Disintegration equipment after Weißmann

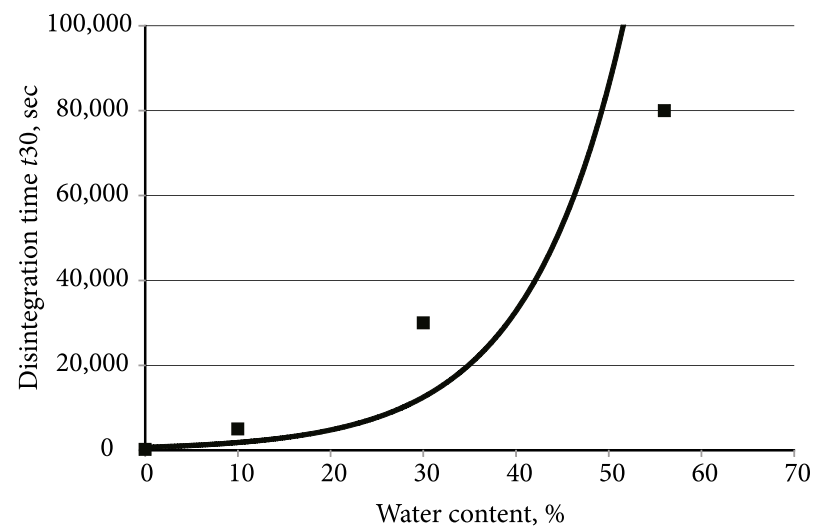

Fig. 4. Diagram of disintegration time depending on water content after Weißmann 
Figure 4. After entering the results of the three test series into this diagram the disintegration number $t_{30, V}$ can be calculated with Equations (2)-(5).

For determining the auxiliary parameters $\mathrm{A}$ and $\mathrm{B}$ (Eqns (3) and (4)) two not defined water contents have to be chosen and the associated disintegration times have to be taken out from the diagram. The reference value $t_{30, V}$ is used at a Consistency Index $I c=0.8$ depending on the associated water content $w_{v}$, which can be calculated from the liquid and the plastic limit (Eqn (5)). Finally the disintegration time $t_{30, V}$ can be calculated at $w_{v}$ with Equation (2):

$$
\begin{gathered}
t_{30}(w)=t_{30,0}+A \cdot w \cdot e^{B \cdot w} \\
B=\frac{\ln \left(\left(\mathrm{t}_{30(\mathrm{w} 1)}-\mathrm{t}_{30,0}\right) \cdot \mathrm{w} 2\right)-\ln \left(\left(\mathrm{t}_{30(\mathrm{w} 2)}-\mathrm{t}_{30,0}\right) \cdot \mathrm{w} 1\right)}{w_{1}-w_{2}} \\
A=\frac{\mathrm{t}_{30(\mathrm{w} 1)}-\mathrm{t}_{30,0}}{w_{1} \cdot e^{B \cdot w 1}} \\
w_{V}=0.2 \cdot w_{L}+0.8 \cdot w_{P}
\end{gathered}
$$

where: $t_{30,0}$ - disintegration time $t_{30}$ at $w=0 \% ; A, B$-auxiliary parameter; $w_{v}$ - water content at $I c=0.8$.

\subsection{Modification of the test procedure for the dredged materials}

Initial tests showed difficulties in evaluating the results of the dredged materials with both tests. Therefore, some modifications were necessary. For a better understanding of the modifications, the original attributes of the Endell and Weißmann tests are compared in Table 4.

For the Endell test one sample at natural water content $w_{n}$ and two samples with water contents $w>w_{n}$ and $w<w_{n}$ were chosen respectively. Samples with $w<w_{n}$ were dried step by step until the selected water content was achieved. To produce samples with $w>w_{n}$ water was added and the material was mixed. Both water addition and sample drying were restricted to values in an interval in which good compaction could be ensured for all samples. The wire mesh basket was made cylindrical having a mesh size of $8 \mathrm{~mm}$ and a diameter and height of 3.2 and $5 \mathrm{~cm}$ respectively. In this way the small samples would not fall through the mesh and could be installed upright inside the basket.

The experiments after Weißmann were modified after initial tests with the dredged materials. Instead of the optimum water content the natural water content was used for sample preparation. The proposed optimal water content at Proctor's density of the inhomogeneous dredged materials could not be determined reliably. Also, all samples compacted at natural water content showed little spread in the disintegration curve and so ensured comparability of all three repetitions.
For both tests the recording interval with respect to weight loss was chosen to $5 \mathrm{~s}$ to ensure a precise measurement of the disintegration during the first few minutes of testing. Every subsample was tested for at least 24 hours.

Table 4. Differences between the tests of Endell and Weißmann

\begin{tabular}{lll}
\hline & \multicolumn{1}{c}{ Endell } & \multicolumn{1}{c}{ Weißmann } \\
\hline Water type & Distilled water & Tap water \\
\hline \multirow{3}{*}{ Basket } & Not defined. Chosen: & Defined: Size: \\
& Size; $3.2 \times 5.0 \mathrm{~cm}^{2}$, & $10 \times 10 \times 12 \mathrm{~cm}^{3}$, \\
& $8 \mathrm{~mm}$ mesh & $8 \mathrm{~mm}$ mesh \\
\hline Sample size & $H=4 \mathrm{~cm}, D=2 \mathrm{~cm}$ & $H=D=5 \mathrm{~cm}$ \\
\hline \multirow{2}{*}{ Result } & Disintegration number & Disintegration time \\
& $Z(t)$ & $t_{30}$ \\
\hline
\end{tabular}

\section{Results}

\subsection{Disintegration test after Endell}

\subsubsection{Dredged materials M1, M2 and M3}

The results of the disintegration test are the process of disintegration as a function of the time and computed a disintegration number after eight hours. The functions of material M1 and M2 have similar shapes. Figure 5 shows the measured relative sample weight of material M1 relating to the disintegration time.

Already after a short time all samples start to crumble and large aggregates fall off to the bottom of the water basin which can be seen from the recorded scale data. This process generally dominates in a time interval of 10 to $1,000 \mathrm{~s}$. As soon as the samples have lost about $50-70 \%$ of their initial weight this process seems to stop; for the rest of the time the recorded weight remains nearly constant. However, there seems to be an exception for samples with low water contents: shortly after the start the dry material absorbs water and the weight increases to about $120 \%$ of the initial weight. After some time the increase stops and the recorded weight shows both the largest and fastest decrease among all samples.

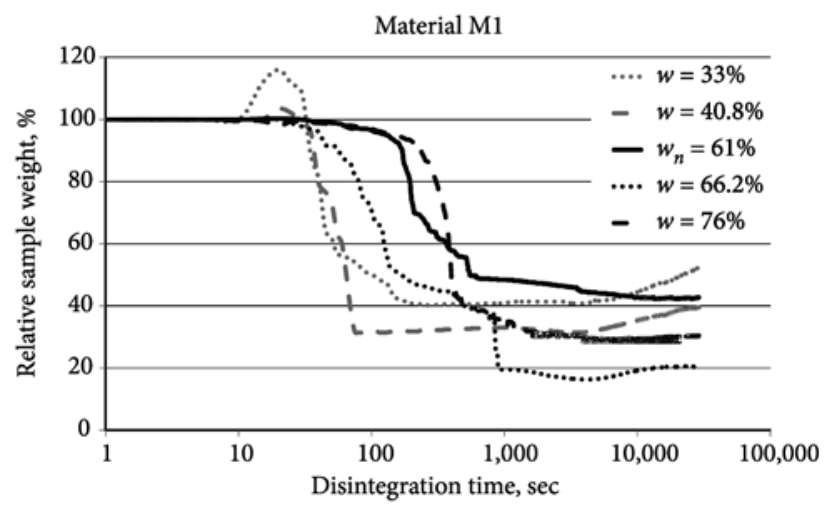

Fig. 5. Disintegration curves (Endell) of material M1 
Table 5. Disintegration number $Z(8)$ of material M1 and M2

\begin{tabular}{ccc}
\hline Material & $w[\%]$ & $Z(8)$ after $8 \mathrm{~h}$ \\
\hline \multirow{3}{*}{ M1 } & 33.0 & 0.7273 \\
& 40.8 & 0.6056 \\
& $w_{n}=61.0$ & 0.5728 \\
66.2 & 0.6954 \\
& 76.0 & 0.6056 \\
\hline \multirow{3}{*}{ M2 } & 30.0 & 0.7273 \\
& 42.0 & 0.3991 \\
& $w_{n}=54.0$ & 0.4714 \\
& 78.0 & 0.4784 \\
& 79.0 & 0.6348 \\
\hline
\end{tabular}

Table 6. Disintegration number $Z(8)$ of material M3

\begin{tabular}{ccc}
\hline Material & $w[\%]$ & $Z(8)$ after $8 \mathrm{~h}$ \\
\hline & 21.9 & 0.9206 \\
& 36.0 & 0.9958 \\
M3 & 36.9 & 0.7273 \\
& 49.1 & 0.8033 \\
& $w_{n}=49.7$ & 0.5425 \\
& 54.6 & 0.9524 \\
& 57.8 & 0.9003 \\
\hline
\end{tabular}

Later during the test the initially dry samples seem to start to absorb water again, resulting in a second weight gain. The analysis of the disintegration numbers after eight hours show the lowest disintegration (the best erosion stability) for the natural water content $w_{n}$ for material M1 and for a water content below $w_{n}$ for material M2. Table 5 gives an overview about the disintegration numbers $Z(8)$ of the materials M1 and M2.

The more sandy dredged material M3 shows a different set of disintegration curves. Almost all samples show a high disintegration rate. The sample weight reduces to nearly zero within approximately $100 \mathrm{~s}$ with the exceptions of the samples with $w_{n}=49.7 \%$ and $w=36.9 \%$. The dry samples also show an initial weight increase to $110 \%$ comparable to the materials M1 and M2. Interestingly, there are samples with nearly the same water content which show very different disintegration behaviour: the sample with $w=49.1 \%$ shows a significantly higher disintegration number than that with $w_{n}=49.7 \%$. A similar observation was made for $w=36.0 \%$ and $w=36.9 \%$ (Fig. 6 and Table 6).

\subsubsection{Conventional dike construction material marl and marsh clay}

The development of the marl disintegration partly differs from that of the dredged materials, in particular regarding materials M1 and M2. Compared to the dredged materials, the tested marl can only absorb little amounts of water because of its large sand and small clay fraction. The maximum possible water content to produce proctor samples was $w=14.1 \%$. The crumbling of the different marl samples proceeded very fast and in steps (Fig. 7).

The sample with the natural water content shows the lowest disintegration number, a result that was also found for the dredged materials M1 and M3 (Table 7). Some samples even show a full disintegration like material M3.

The investigated marsh clay shows an explicit distinction of the disintegration curves with respect to the water contents of the subsamples (Fig. 8).

The best result was again achieved with the $w_{n}$ sample. The driest sample crumbled fastest with a total weight loss of $98 \%$ and a very high disintegration number $Z(8)=$ 0.9874 (Table 8$)$. The disintegration numbers with $Z(8)=$ 0.2589 and $Z(8)=0.2834$ for the samples with $w_{n}$ and $w=$ $23 \%$ are the best results of all materials tested.

Table 7. Disintegration number Z(8) of marl

\begin{tabular}{ccc}
\hline Material & $w[\%]$ & $Z(8)$ after $8 \mathrm{~h}$ \\
\hline \multirow{4}{*}{ Marl } & 5.6 & 1.0 \\
& 7.8 & 0.8823 \\
& 9.2 & 0.9821 \\
& $w_{n}=11.8$ & 0.6838 \\
14.8 & 0.807 \\
\hline
\end{tabular}

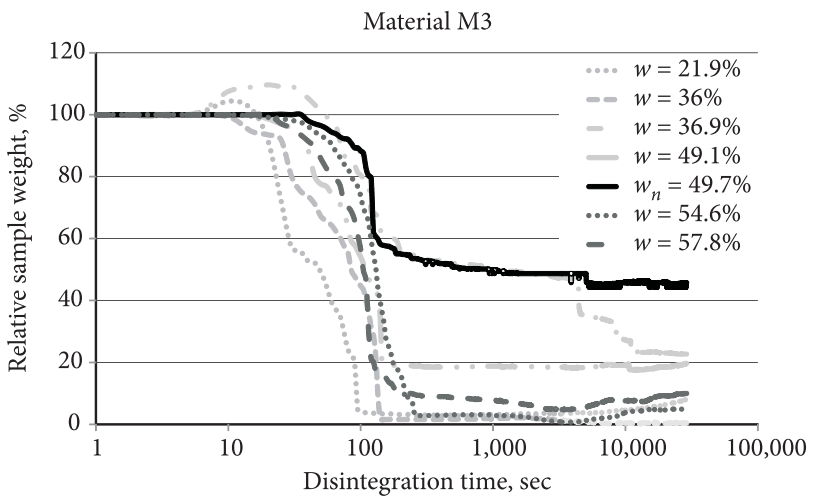

Fig. 6. Disintegration curves (Endell) of material M3

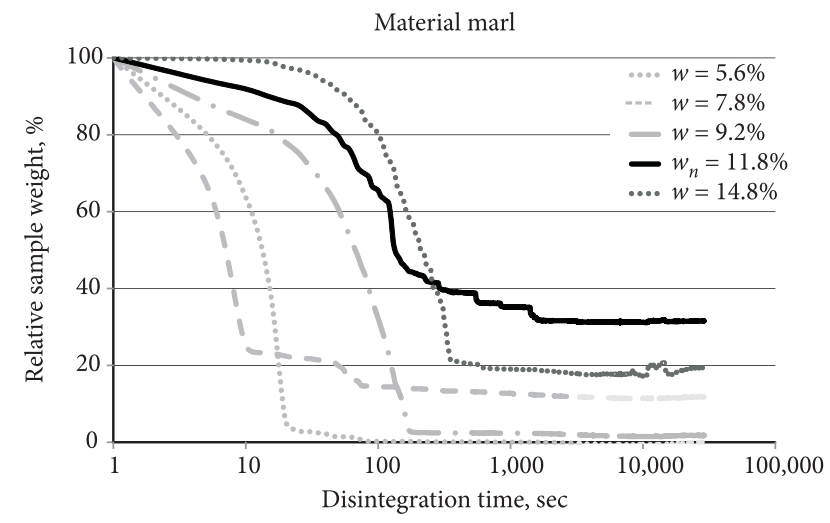

Fig. 7. Disintegration curves (Endell) of marl 


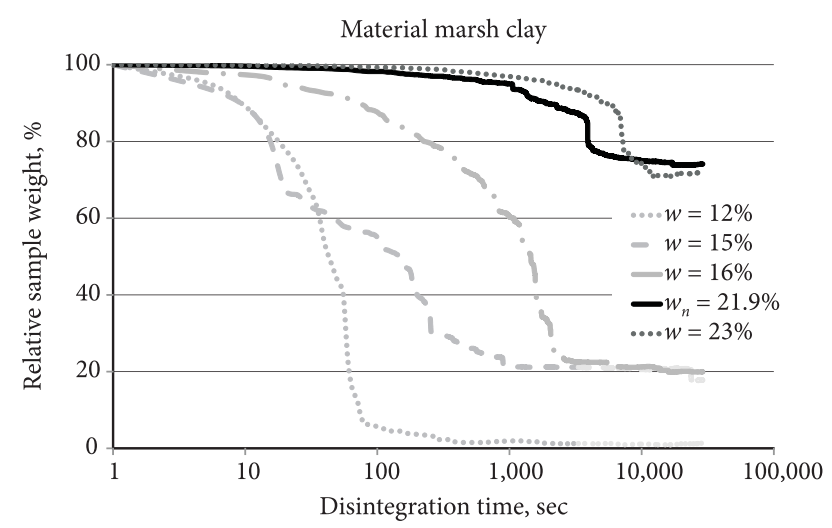

Fig. 8. Disintegration curves (Endell) of marsh clay

Table 8. Disintegration number $Z(8)$ of marsh clay

\begin{tabular}{ccc}
\hline Material & $w[\%]$ & $Z(8)$ after $8 \mathrm{~h}$ \\
\hline & 12.0 & 0.9874 \\
Marsh & 15.0 & 0.8216 \\
clay & 16.0 & 0.8008 \\
& $w_{n}=21.9$ & 0.2589 \\
& 23.0 & 0.2834 \\
\hline
\end{tabular}

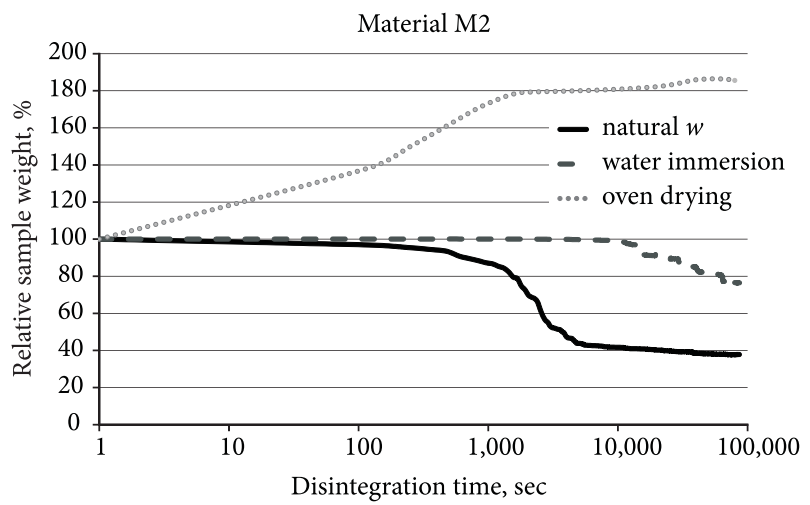

Fig. 9. Disintegration curves (Weißmann) of material M2

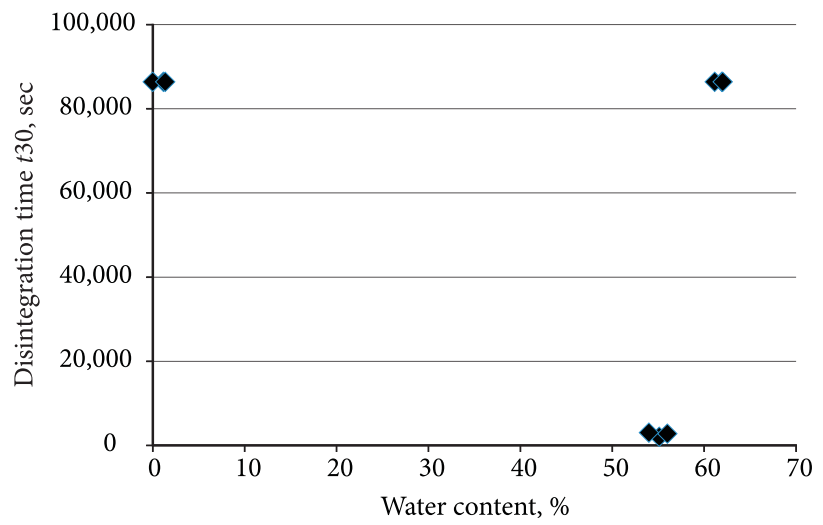

Fig. 10. Disintegration time $t_{30}$ depending on water content for material M2

\subsection{Disintegration test after Weißmann}

\subsubsection{Dredged materials M1, M2 and M3}

The results of the disintegration tests after Weißmann are the disintegration curves as functions of time as well as the disintegration time $t_{30}$ for three defined water contents. Depending on the available amount of material two subsamples were chosen for the investigation of materials M1 and M2 and only one for material M3. Since all dredged materials show similar curve shapes for the different sample preparation modes the curves of M2 are presented exemplary (Fig. 9).

The weight of the oven-dried samples started to increase constantly as soon as they were submerged. The weight gain approached up to $260 \%$ of the initial weight although aggregates had fallen off the sample. During the test large air bubbles were observed to come out of the soil sample.

The "water immersion" samples which were initially wrapped in filter paper show the highest stability. For a considerable period of time these samples did not lose significant weight before they started to crumble after about 10,000 s. However, there are also intervals in with no weight change was recorded although particles fell of the sample. At the end of the test the water immersion samples started to disintegrate to a relative weight loss of about $20 \%$ with no further change.

The $w_{n}$ samples show the highest disintegration of the three conditions. They usually started to crumble after about $1,000 \mathrm{~s}$ and show a final weight loss of about $60 \%$.

Because both the oven-drying and the water-immersion samples show no weight loss of $30 \%$ the disintegration time has to be defined to $86,400 \mathrm{~s}$ which is why no exponential disintegration curve can be determined (Fig. 10).

The dependency of disintegration and water content cannot be described with this data and consequently no disintegration time $t_{30, V}$ can be calculated. Only the disintegration time after $30 \%$ mass loss of the samples with natural water content can be determined and compared (Table 9).

Table 9. Disintegration time $t_{30}\left(w_{n}\right)$ of M1, M2 and M3

\begin{tabular}{cc}
\hline Material & Disintegration time $t_{30}\left(w_{n}\right)[\mathrm{s}]$ \\
\hline M1 & 1.600 and 1.320 \\
M2 & 2.600 and 4.000 \\
M3 & 1.120 \\
\hline
\end{tabular}

\subsubsection{Conventional dike construction material marl and marsh clay}

The marl samples show a different behaviour. After few seconds all samples started to crumble and lost a large 
amount of mass within a short period of time (Fig. 11). After 2,000 s the disintegration was already finished with a final weight of 20 to $30 \%$ of the initial mass.

As distinguished from the investigations with dredged material the optimal water content $w_{\text {opt }}$ was used instead of the oven-dried because the oven-dried samples showed only weight increase instead of mass loss. For further results of the disintegration of oven-dried marsh clay samples compare Beyer et al. (2012). For the installation of $w_{\text {opt }}$ the material was oven dried at $55^{\circ} \mathrm{C}$ and rewetted afterwards. The result of the disintegration time at $w_{v}$ is $t_{30, V}=731$ s (Table 10).

Table 10. Disintegration time $t_{30}$ of marl

\begin{tabular}{ccc}
\hline Parameter & $w[\%]$ & $t_{30}[\mathrm{~s}]$ \\
\hline$w_{n}$ & 11.5 & 482 \\
$w_{i m}$ & 12.43 & 672 \\
$w_{\text {opt }}$ & 12.0 & 178 \\
$w_{v}$ & 13.72 & 731 \\
\hline
\end{tabular}

Table 11. Disintegration time $t_{30}$ of marsh clay

\begin{tabular}{ccc}
\hline Parameter & $w[\%]$ & $t_{30}[\mathrm{~s}]$ \\
\hline$w_{n}$ & 24.0 & 60,098 \\
$w_{i m}$ & 43.71 & 86,400 \\
$w_{\text {opt }}$ & 13.4 & 373 \\
$w_{v}$ & 25.08 & 62,438 \\
\hline
\end{tabular}

The disintegration curves of marsh clay show that the crumbling of samples with $w_{n}$ started late and the disintegration of $30 \%$ was reached very late: $t_{30}=60,000 \mathrm{~s}$. The "water immersion" samples show hardly any mass loss during the whole investigation (maximum 2\%). The samples with $w_{\text {opt }}$ on the contrary showed a result comparable to that of the marl. Here, crumbling started already after $100 \mathrm{~s}$ and resulted in an almost complete mass loss (Fig. 12). The disintegration time at $w_{v}$ is $t_{30, V}=62,438 \mathrm{~s}$ (Table 11).

\section{Discussion}

During the investigation both benefits and major limitations of the different disintegration tests could be observed. There is a general problem of both tests with respect to the testing procedure - a sample in a wire basket submerged in water. However, the two experimental setups show test specific limitations also. Finally, the results are discussed in comparison to test results from a dynamic erosion test using a small scale laboratory flume and to data taken from the literature.

\subsection{Testing procedure}

The testing procedure of both disintegration tests is based on a sample inside a wire mesh basket which is submerged

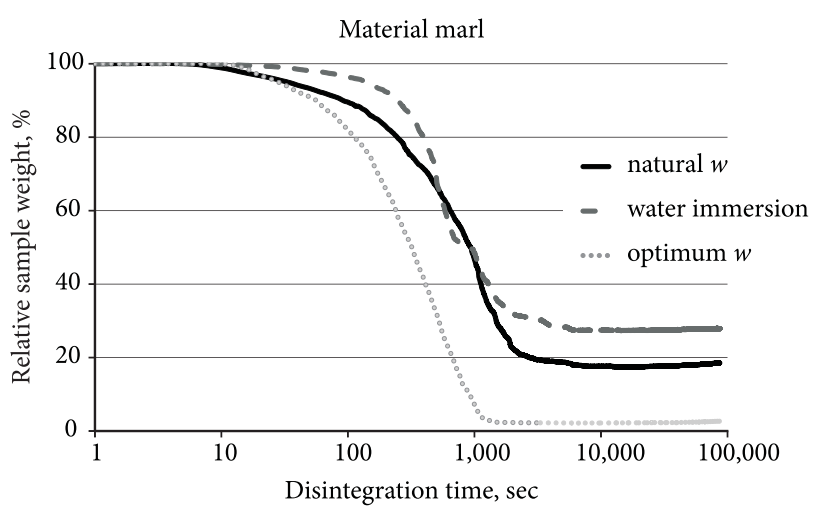

Fig. 11. Disintegration curves (Weißmann) of marl

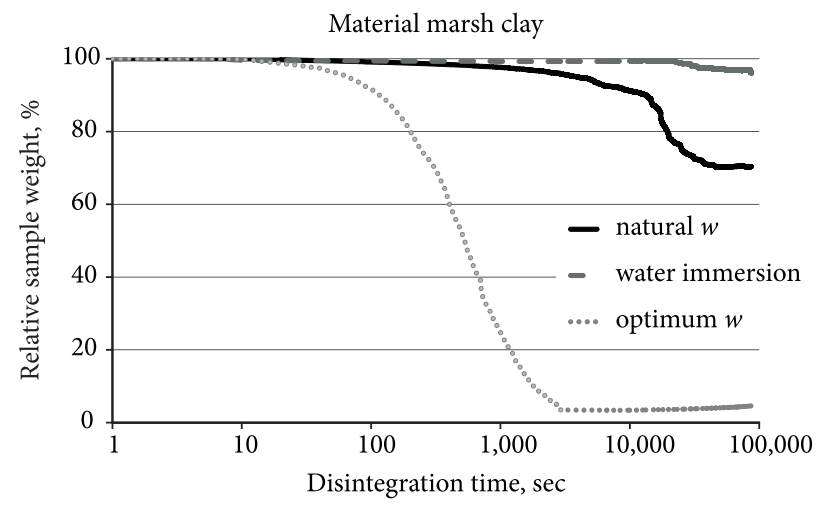

Fig. 12. Disintegration curves (Weißmann) of marsh clay
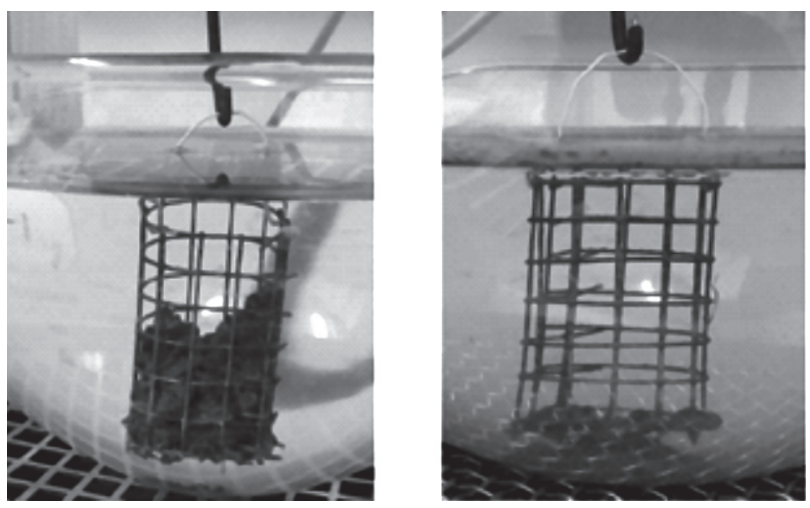

Fig. 13. Total disintegration with different mass loss

in water. The major limitation of this procedure which was observed in a large variety of test is, that soil aggregates that fall off the sample during disintegration stay in the basket and are not detected as disintegration by weight loss (Fig. 13 left).

This may have different reasons such as the defined small mesh size in case of the Weißmann test together with varying sizes of agglomerates that evolve during disintegration. In Figure 13 both samples are completely disintegrated with the difference that the disintegration is recorded correctly for the right sample and no weight loss is recorded for the left sample. For the Endell test the RPW (2006) 
proposes to repeat the test until there is one test in which all aggregates fall down. There may be soil samples, however, which always decompose into larger aggregates where this solution will not solve the problem. Weißmann, on the other hand, gives no attention to this problem. The problem may be solved by using baskets with different mesh sizes; this may not affect the Endell method (no definitions with respect to the basket) but an adjustment to the Weißmann method would be needed. To compare different disintegration tests the same mesh size should be used, thus this parameter needs to be recorded for every test.

\subsection{Disintegration test after Endell}

In RPW (2006) the disintegration number after eight hours $Z(8)$ is used to specify a soil's susceptibility to erosion. The value of $Z(8)=0.05$ above which a soil is considered erodible has been developed for mineral sealing liners. In this investigation dredged material, marl and marsh clay were tested which may perform differently with respect to the disintegration number and the actual erosion resistance. This may be caused by the materials' lower clay content compared to that of mineral sealing liners.

The lowest disintegration number was determined at $w_{n}$ for the majority of samples. The most substantive explanation seems to be connected to the sample preparation which was necessary to install the different water contents. Some of the samples needed to be dried, which seems to have a considerable influence on the aggregate stability, particularly for the fine-grained, organic materials. The influence of the drying temperature in soil sample preparation on the aggregation has already been investigated by different researchers (Basma et al. 1994; Sunil, Krishnappa 2012). These investigations show that a higher drying temperature leads to an accumulation of fine particles with organic and to larger grains with decreasing specific surface area (Mikutta et al. 2005). There is also an irreversible dehydration process of the clay particles causing cementation of fine particles which are then not dispersed (Sunil, Krishnappa 2012). These effects can even be detected in a standard grainsize analysis. The "reduction" of fine particles also reduces their cementing ability and the samples start to crumble faster.

A second explanation may be found in the fast infiltration of the dried materials once they are submerged which leads to a quick displacement of air confined in the soil sample (Rohoskova, Valla 2004). Large air bubbles escape the samples due to over-pressure, usually causing "aggregate blasting" (Auerswald 1993; Le Bissonnais 1996)

For dredged materials the preparation with water addition leads to a higher disintegration. At the beginning higher water contents lead to less crumbling because more micro-pores are pre-filled with water. Then the behaviour changes and more aggregates fall off, possibly because the aggregate cohesion is weakened through the initial water immersion. No dependences of disintegration and water content could be found for the dredged materials (compare Rudat 2012).

According to Dal Ferro et al. (2012) and Cantón et al. (2009) there is a stabilisation of aggregates by organic carbon. In the investigation no correlation between organic content and disintegration could be validated. Both finegrained dredged materials M1 and M2 have high organic and clay contents but show lower erosion resistance than marsh clay with less organic content.

To compare the erosion resistance of the different materials the disintegration number $Z(8) w_{n}$ was chosen (Table 12). The conventional dike construction material marsh clay has the lowest disintegration number $Z(8)=$ 0.2589 , followed by the dredged material M2 with $Z(8)=$ 0.4714 . The maximum disintegration could be observed for dredged material M1 and marl.

All materials - including the conventional dike construction materials - did not even closely achieve a value of $Z(8)<0.05$ which is the proposed erosion resistance limit for mineral liners. If the disintegration test after Endell shall be used for dike construction materials the disintegration value needs modification.

Table 12. Disintegration number $Z(8), w_{n}$ in comparison

\begin{tabular}{cc}
\hline Sample & $Z(8), w_{n}$ \\
\hline M1 & 0.5728 \\
M2 & 0.4714 \\
M3 & 0.5425 \\
Marl & 0.6838 \\
Marsh clay & 0.2589 \\
\hline
\end{tabular}

\subsection{Disintegration test after Weißmann}

In the disintegration tests no dependency of disintegration time $t_{30}$ and water content could be found. All oven-dried samples showed a considerable weight increase of up to $260 \%$ of the initial weight instead of a mass loss, although moderate crumbling could be recognized for all samples. There are two reasons for this phenomenon: the high amount of water which is absorbed and the escaping air bubbles which reduce the buoyancy. According to Beyer et al. (2012) the influence of buoyancy cannot be eliminated in this test procedure. This may lead to questionable results for unsaturated samples.

Due to the missing dependency of water content and disintegration the disintegration time at $I_{p}=0.8$ cannot be determined. Even the modification to use samples with $w_{\text {opt }}$ instead of oven-dried samples does not show any improvement. All samples crumbled in a very short time 
because of the preparation with oven-drying, rewetting and compaction (Lindh, Winter 2003).

To compare all materials the disintegration time at $w_{n}$ was chosen again (Table 13). For materials M1 and M2 two subsamples were investigated respectively, for material M3, marsh clay and marl only one each.

Table 13. Disintegration time $t_{30}$ at natural water content

\begin{tabular}{cc}
\hline Material & $t_{30, w n}[\mathrm{sec}]$ \\
\hline M1 & 1,320 and 1,600 \\
M2 & 2,600 and 4,000 \\
M3 & 1,120 \\
Marl & 482 \\
Clay & 60,098 \\
\hline
\end{tabular}

Like in the Endell test the conventional dike construction material marsh clay shows the best disintegration behaviour among the tested materials. The best result among the dredged materials was obtained with material $\mathrm{M} 2$ with $t_{30, w n}=2,600 \mathrm{~s}$ and $t_{30, w n}=4,000 \mathrm{~s}$. The sandy materials M3 and marl show the poorest results.

Based on his disintegration test Weißmann developed an evaluation method to classify the application of marsh clay as dike construction material. Additional evaluation criteria are water permeability (B1), degree of shrinkage (B3), and plasticity index (B4). As a result an evaluation number $\mathrm{N}$ is determined (Eqns (6)-(10)):

$$
\begin{gathered}
\mathrm{N}=\sqrt[4]{\mathrm{B} 1 \cdot \mathrm{B} 2 \cdot \mathrm{B} 3 \cdot \mathrm{B} 4} ; \\
\mathrm{B} 1=0.7-(\log (\mathrm{kf})+4) / 20 ; \\
\mathrm{B} 2=0.2 \cdot \log \left(\mathrm{t}_{30, \mathrm{~V}}\right) ; \\
\mathrm{B} 3=1.0-1.25 \cdot\left(\mathrm{V}_{\mathrm{S}}-0.05\right) ; \\
\mathrm{B} 4=0.3+2 \cdot \mathrm{I}_{\mathrm{P}} .
\end{gathered}
$$

The evaluation number $N$ can be divided into five suitability classes. Materials with suitability class 1 are very well suited as dike cover layer, while materials with suitability class 5 are not advisable (Table 14). For all materials investigated in this study the evaluation number and suitability class was determined (Table 16). In this case the disintegration time $t_{30, w n}$ was used. The parameters used to compute the evaluation numbers are presented in $\mathrm{Ta}-$ ble 15, partly determined using the "not reliable" results from Table 3.

All investigated materials can be classified at least as class 4 "limited suitability" and are therefore applicable as dike construction materials. The best suitability was determined for the marsh clay (suitability class 2 "well suitable") closely followed by the dredged material M2 (suitability class 3, nearly "well suitable").
Table 14. Suitability classes with respect to the evaluation numbers $N$ (Weißmann 2003)

\begin{tabular}{ccc}
\hline $\begin{array}{c}\text { Valuation } \\
\text { number } N\end{array}$ & $\begin{array}{c}\text { Degree } \\
\text { of suitability }\end{array}$ & $\begin{array}{c}\text { Suitability } \\
\text { class }\end{array}$ \\
\hline $1.00 \geq N \geq 0.85$ & Very well suited & 1 \\
$0.85>N \geq 0.75$ & Well suited & 2 \\
$0.75>N \geq 0.65$ & Suited & 3 \\
$0.65>N \geq 0.50$ & Limited suitability & 4 \\
$N<0.50$ & Not advisable & 5 \\
\hline
\end{tabular}

Table 15. Calculation parameters to determine the evaluation number

\begin{tabular}{lccccc}
\hline Parameter & M1 & M2 & M3 & Marl & $\begin{array}{c}\text { Marsh } \\
\text { clay }\end{array}$ \\
\hline$k_{f}[\mathrm{~m} / \mathrm{s}]$ & $5 \mathrm{E}-08$ & $8 \mathrm{E}-10$ & $2 \mathrm{E}-08$ & $3 \mathrm{E}-08$ & $5 \mathrm{E}-10$ \\
$t_{30}[\mathrm{sec}]$ & 1,320 & 2,600 & 1,120 & 482 & 60,098 \\
$V_{s}[-]$ & 0.33 & 0.26 & 0.176 & 0.026 & 0.1886 \\
$I_{p}[-]$ & 0.051 & 0.157 & 0.028 & 0.041 & 0.139 \\
\hline
\end{tabular}

Table 16. Evaluation numbers $N$ and suitability classes (SC)

\begin{tabular}{cccccc}
\hline & M1 & M2 & M3 & Marl & $\begin{array}{c}\text { Marsh } \\
\text { clay }\end{array}$ \\
\hline B1 & 0.865 & 0.955 & 0.885 & 0.876 & 0.965 \\
B2 & 0.624 & 0.683 & 0.610 & 0.537 & 0.956 \\
B3 & 0.750 & 0.750 & 0.843 & 1.000 & 0.827 \\
B4 & 0.200 & 0.614 & 0.200 & 0.200 & 0.578 \\
N & 0.533 & 0.740 & 0.549 & 0.554 & 0.815 \\
SC & 4 & $3(+)$ & 4 & 4 & 2 \\
\hline
\end{tabular}

\subsection{Comparison of disintegration tests with investigations in a laboratory flume}

In the project DredgDikes full scale overflowing tests on dike slopes are planned to determine the surface erosion stability of the dredged materials M1-M3. For preliminary tests a small scale laboratory flume was used with dimensions of $2.90 \mathrm{~m}$ length and $0.25 \mathrm{~m}$ width and a variable slope inclination with a maximum of $3: 1$. With the associated pumps a flow velocity of $2.3 \mathrm{~m} / \mathrm{s}$ and an associated shear stress of $210 \mathrm{~N} / \mathrm{m}^{2}$ can be realised. For the experimental tests 20 samples (ten vegetated and ten non-vegetated samples) with a thickness of $7 \mathrm{~cm}$ prepared from the dredged materials M1, M2 and M3 and tested in the flume. The degree of compaction ranged from 0.6-0.85. For reference the conventional dike construction material marsh clay was used. For the nonvegetated samples an erosion rate was determined using laser scan data as the quotient of the eroded soil volume and the volume of water.

The marsh clay showed by far the lowest erosion rate, while material M2 showed the best results among the 


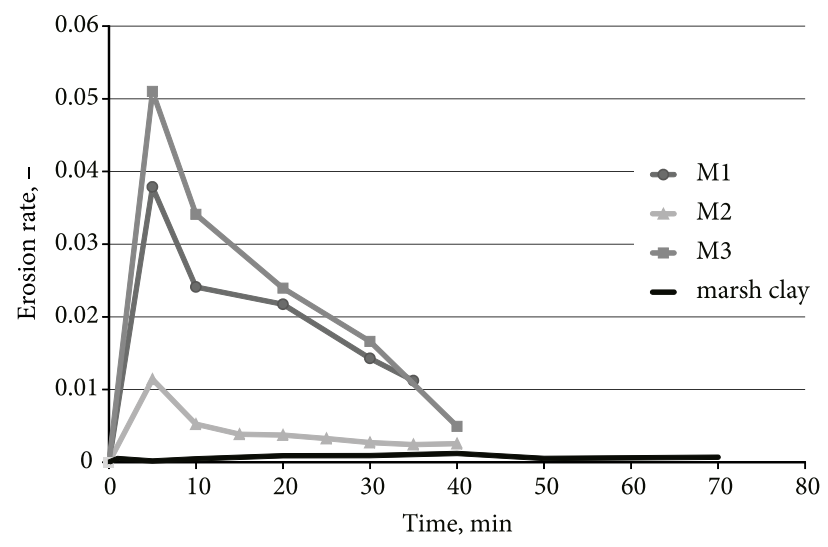

Fig. 14. Erosion rates of dredged material and marsh clay (modified after Lesch 2012)

dredged materials (Fig. 14). The samples of materials M1 and M3 in comparison experienced four to five time the erosion of M2.

When comparing the results of the flume test with those of the disintegration tests the single value of each test is related to the marsh clay values, because the lowest erosion in all investigations have been obtained at these samples. Altogether, similar orders of magnitudes can be recognized especially between the Weißmann test and the laboratory flume (Table 17), whereas the Endell test results show a smaller difference between the disintegration of marsh clay and the dredged materials. The reasons for this may be the small Endell test samples which are quickly wetted, leading to a comparably fast disintegration of all samples.

Table 17. Comparison of orders of magnitudes of disintegration tests and laboratory flume

\begin{tabular}{lcccc}
\hline & M1 & M2 & M3 & $\begin{array}{c}\text { Marsh } \\
\text { clay }\end{array}$ \\
\hline Lab flume & 31 & 9 & 45 & 1 \\
Endell & 2.2 & 1.8 & 2.1 & 1 \\
Weißmann & 38 & 15 & 54 & 1 \\
\hline
\end{tabular}

\section{Conclusions}

The use of dredged materials in dike construction is an important contribution to environmental protection engineering since a legal waste is beneficially re-used in environmental constructions. For the characterisation of the materials the erosion stability has to be investigated. During the investigations both benefits and major limitations of disintegration tests could be observed. The following conclusions can be drawn:

1. There is a major problem with the small mesh size in the Weißmann test facility and there are limitations with respect to the varying agglomerate sizes. In case of the Endell test the proposal of RPW to repeat the test until there is one in which all particles fall through the mesh is problematic with respect to the agglomerations that characterise a fine-grained organic dredged material. For the small mesh size proposed there may not be one such result.

2. The sample preparation with drying and rewetting of cohesive organic soils has a considerable influence on the aggregate stability and complete drying should be avoided.

3. The sample preparation methods for disintegration tests need to be modified for cohesive organic soils.

4. In both disintegration test setups no dependency between disintegration time and water content could be found. All oven-dried samples show an increase of the initial weight instead of a mass loss, although moderate crumbling could be recognized. Thus the modification of different test conditions should be considered.

5. Disintegration tests can be used to determine qualitative disintegration differences between materials using samples prepared at natural water content $\mathrm{w}_{\mathrm{n}}$.

6. The disintegration tests after Endell and Weißmann cannot be used to compute the quantitative aggregate stability for cohesive organic soils yet.

7. The results of the study on disintegration tests shows that there is still work needed to establish a laboratory test that allows to determine the erosion stability of fine-grained organic soils to be used in geotechnical constructions in environmentally sensitive areas such as coastal lowlands. The presented determination of benefits and limitations of the existing tests together with an analysis of necessary adaptions and boundary conditions pave the way for environmental engineers to discuss this development.

\section{Acknowledgements}

A special thanks to the Faculty of Interdisciplinary Research, Department Maritime Systems (University of Rostock) for a scholarship in the frame of which most of the results were derived.

\section{References}

Ametzketa, E. 1999. Soil aggregate stability: a review, Journal of Sustainable Agriculture 14(2-3): 83-151. http://dx.doi.org/10.1300/J064v14n02_08

Auerswald, K. 1993. Relief-Boden-Paläoklima - Bodeneigenschaften und Bodenerosion - Wirkungswege bei unterschiedlichen Betrachtungsmaßstäben [Relief-Soil-Paleoclimate - soil characteristics and soil erosion], Berlin - Stuttgart: Gebrüder Borntraeger. 208 p. (in German).

Basma, A.; Al-Homoud, A.; Al-Tabari, E. 1994. Effects of methods of drying on the engineering behavior of clays, Applied Clay Science 9(3): 151-164. http://dx.doi.org/10.1016/0169-1317(94)90017-5 
Beyer, K.; Grabe, J.; Timmers, V. 2012. Zum Verhalten von Deichabdeckungen aus METHA-Material und Klei bei Vernässung [On the behaviour of dike covers made of METHA material and marsh clay with increasing water content], Siegen Symposium, 23-24 February 2012, Siegen. 16 p. (in German).

Blume, H.-P.; Brümmer, G.; Horn, R.; Kandaler, E.; Kögel-Knabner, I.; Kretzschmar, R.; Stahr, K.; Wilke, B.-M. 2010. Scheffer/Schachtschabel - Lehrbuch der Bodenkunde [Soil science]. Heidelberg: Spektrum Akademischer Verlag. 569 p. (in German). http://dx.doi.org/10.1007/978-3-8274-2251-4

Briaud, J. L.; Ting, F. C. K.; Chen, H. C.; Cao, Y.; Han, S. W.; Kwak, K. W. 2001. Erosion function apparatus for scour rate prediction, Journal of Geotechnical and Geoenvironmental Engineering American Society of Civil Engineers 127(2): 105-113. http://dx.doi.org/10.1061/(ASCE)1090-0241(2001)127:2(105)

Canet, R.; Chaves, C.; Pomares, F.; Albiach, R. 2003. Agricultural use of sediments from the Albufera Lake (Eastern Spain), Agricultural Ecosystems \& Environment 95(1): 29-36. http://dx.doi.org/10.1016/S0167-8809(02)00171-8

Cantón, Y.; Solé-Benet, A.; Asensio, C.; Chamizo, S.; Puigdefábregas, J. 2009. Aggregate stability in range sandy loam soils relationships with runoff and erosion, Catena 77(3): 192-199. http://dx.doi.org/10.1016/j.catena.2008.12.011

Cantré, S.; Saathoff, F. 2013. Investigation of Dredged materials in combination with geosynthetics used in dike construction, Procedia Engineering 57: 213-221.

http://dx.doi.org/10.1016/j.proeng.2013.04.030

Chenu, C.; Le Bissonnais, Y.; Arrouays, D. 2000. Organic matter influence on clay wettability and soil aggregate stability, Soil Sciences Society of America 64(4): 1479-1486. http://dx.doi.org/10.2136/sssaj2000.6441479x

Dal Ferro, A.; Berti, A.; Francioso, O.; Ferrari, E.; Matthews, G. P.; Morari, F. 2012. Investigating the effects of wettability and pore size distribution on aggregate stability: the role of soil organic matter and the humic fraction, European Journal of Soil Science 63(2): 152-164.

http://dx.doi.org/10.1111/j.1365-2389.2012.01427.x

Haghighi, I.; Martin, T.; Reiffsteck, P.; Chevalier, C. 2012. An "Enhanced Crumb Test" for better characterizing water sensivity of soils, in $6^{\text {th }}$ ICSE Proceedings, 27-31 August 2012, Paris, France, 1049-1056.

Hartge, K.; Horn, R. 2009. Die physikalische Untersuchung von Böden [The physical investigation of soils]. Stuttgart: E. Schweizerbart'sche Verlagsbuchhandlung. 178 p. (in German).

Le Bissonnais, Y. 1996. Aggregate stability and assessment of soil crustability and erosibility: I. Theory and methodology, in European Journal of Soil Science 47(4): 425-437. http://dx.doi.org/10.1111/j.1365-2389.1996.tb01843.x

Lesch, S. 2012. Projekt DredgDikes - Ermittlung der Erosionsstabilität gegen Überströmen von begrüntem Baggergut in einer kleinmaßstäbigen Strömungsrinne [Project DredgDikes - Determination of the erosion stability against overflowing of greened dredged material in a small-scale flume]: Master's Thesis. Universität Rostock. 100 p. (in German).

Lindh, P.; Winter, M. G. 2003. Sample preparation effects on the compaction properties of Swedish fine-grained tills, Journal of Engineering, Geology and Hydrogeology 36(4): 321-330.

Mikutta, R.; Kleber, M.; Kaiser, K.; Jahn, R. 2005. Review: organic matter removal from soils using hydrogen peroxide, sodium hypochlorite, and disodium peroxodisulfate, Soil Science Society of America 69(1): 120-135. http://dx.doi.org/10.2136/sssaj2005.0120

Rohoskova, M.; Valla, M. 2004. Comparison of two methods for aggregate stability measurement - a review, Plant Soil Environment 50(8): 379-382.

RPW 2006. Guidelines for the Testing of Mineral Liners in Waterways Engineering, EU-Notifizierung Nr. 2006/370/D vom 23.10.2006 (in German).

Rudat, M. 2012. Untersuchungen zur Erosionsstabilität von feinkörnigem Baggergut mittels Zerfallstest [Investigations on the erosion stability of fine-grained dredged material using disintegration tests]: Master's Thesis. Universität Rostock. 104 p. (in German).

Sigua, G. C.; Holtkamp, M. L.; Coleman, S. W. 2004. Assessing the efficacy of dredged materials from Lake Panasoffkee, Florida, Implication to Environment and Agriculture 11(5): 321-326.

Sunil, B.; Krishnappa, H. 2012. Effect of drying on the index properties of lateritic soils, Geotechnical and Geological Engineering 30(4): 869-879. http://dx.doi.org/10.1007/s10706-012-9504-7

Weißmann, R. 2003. Die Widerstandsfähigkeit von Seedeichbinnenböschungen gegenüber ablaufendem Wasser [The resistance capacity of landside sea dike embankments against overflowing water], Mitteilungen aus dem Fachgebiet Grundbau und Bodenmechanik. University Duisburg-Essen. 147 p. (in German).

\section{Standards and regulations}

ASTM D 4221-99 (Reapproved 2005): 2005. Standard Test Method for Dispersive Characteristics of Clay Soil by Double Hydrometer. ASTM International, West Conshohocken, PA, USA.

ASTM D 4647-06: 2006. Standard Test Method for Identification and Classification of Dispersive Clay Soils by the Pinhole Test. ASTM International, West Conshohocken, PA, USA.

ASTM D 6572-06: 2006. Standard Test Methods for Determining Dispersive Characteristics of Clayey Soils by the Crumb Test. ASTM International, West Conshohocken, PA, USA.

BBodSchG: 1998. Gesetz zum Schutz vor schädlichen Bodenveränderungen und zur Sanierung von Altlasten (Bundes-Bodenschutzgesetz-BBodSchG) [Federal Soil Protection Act]. 12 p. (in German).

BBodSchV: 1999. Bundes-Bodenschutz- und Altlastenverordnung (BBodSchV) [Federal Soil Protection and Contamination Ordinance]. 32 p. (in German).

DIN-Taschenbuch 113, 1998. Erkundung und Untersuchung des Baugrundes [Ground investigation and testing], Berlin: Beuth-Verlag. 437 p. (in German).

DIN ISO 10694: 1996. Soil quality - Determination of organic and total carbon after dry combustion (elementary analysis) (in German).

DIN ISO 11277: 2002. Soil quality - Determination of particle size distribution in mineral soil material - Method by sieving and sedimentation (in German).

DIN 19683-16: 2009. Soil quality - Physical laboratory tests - Part 16: Determination of aggregate stability using the method of wet-sieving (in German).

WHG: 2009. Gesetz zur Ordnung des Wasserhaushaltes (Wasserhaushaltsgesetz - WHG) [Federal Water Act]. 56 p. (in German). 
Anne-Katrin GROßE. Since 2013, Research Assistant at the Chair of Geotechnics and Coastal Engineering. 2003-2008: University of Rostock, studies in Land Management and Environmental Protection; specialization in Environmental Geotechnics and Landscape Construction. 2009-2013: PhD-scholarship of the Faculty of Interdisciplinary Research, Department Maritime Systems (University of Rostock), topic in dredged materials in dike construction. She is the author of 2 conference presentations with published paper contributions. Research interests include: soil mechanical characterization and erosion stability of ripened dredged materials.

Stefan CANTRÉ. 1995-2001 University of Rostock, education in Land Management and Environmental Protection; specializations in Landscape Planning, Geotechnics, Landscape Construction and Geosynthetics. 1998: University of Natural Resources and Life Sciences, Vienna; specialization in Rural Engineering and Water Management as well as Torrent and Avalanche Control; 1998-1999: Heriot-Watt University in Edingburgh, Scotland, College of Art, School of Planning and Housing and School of Landscape Architecture; Since 2001 Research Assistant at the Chair of Geotechnics and Coastal Engineering. In 2008, Graduation at the University of Rostock, topic: A contribution to the design of geotextile tubes for the dewatering of dredged materials. 2004-2009: University of Hagen (distance learning), Industrial Engineering. Since 2010, Coordinator of the EU-Project "DredgDikes". Author of 13 journal articles and 18 conference presentations with published paper contributions. Research interests: geosynthetics used for the dewatering of dredged materials, geosynthetic tubes and containers, the applicability of dredged materialsin dike construction, erosion control, including geosynthetic erosion control products.

Fokke SAATHOFF. 1976-1984 University of Hannover, studies in Civil Engineering, specializations in Structural and Hydraulic Engineering. 1981-1991 student and Research Assistant at Franzius-Institute for Hydraulic, Waterways and Coastal Engineering. 1991 Graduation to Dr.-Ing., Franzius Institute for Hydraulic, Waterways and Coastal Engineering; topic in geosynthetics in sealing systems: Laboratory investigations on the behaviour of geotextiles and synthetic liners. 1991-1997 Manager Naue Fasertechnik GmbH \& Co. KG, Lübecke. 1998-2006 Managing Director at BBG Bauberatung Geokunststoffe GmbH \& Co. KG, Lehmförde and Fiestel. Since 2006, Full Professor at the University of Rostock, Chief of the Chair of Geotechnics and Coastal Engineering. Since 2010, Project leader of the EU-Project "DredgDikes". Scientific functions: Vice Dean for Academic Affairs at the Faculty of Agricultural and Environmental Sciences, University of Rostock; Member of the Academic Council of the University of Rostock; Chairman of the Working Group AK 5.4.1: Research Association for Roads and Traffic (FGSV): Erosion Protection; Chairman of the Working Group AK 5.1 of the German Geotechnical Society (DGGT): Synthetics in Geotechnical and Hydraulic Engineering; Chairman of the working group AK 17 "Efficient Revetments at Waterways"; Chairman of the German delegation of the WG 1/CEN TC 189: "specific requirements" and leader of the task group "lining systems". Author of more than 250 publications including journal and conference papers. Uncounted conference participations as well as conference chairman and session leaderships for DGGT, HTG, IGS, etc. Research interest include: Geosynthetics in geotechnics and hydraulic engineering, beneficial reuse of dredged materials, mineral and synthetic filter systems, mineral and synthetic sealing systems, geotechnical and hydraulic aspects of renewable energy systems (e.g. wind power). 